\title{
Study of the effect exerted by fructo-oligosaccharides from yacon (Smallanthus sonchifolius) root flour in an intestinal infection model with Salmonella Typhimurium
}

\author{
Eva Velez ${ }^{1,2}$, Natalia Castillo ${ }^{2}$, Oscar Mesón ${ }^{1}$, Alfredo Grau ${ }^{3}$, María E. Bibas Bonet ${ }^{1}$ \\ and Gabriela Perdigón ${ }^{1,2 *}$ \\ ${ }^{1}$ Cátedra de Inmunología, Facultad de Bioquimíca, Química y Farmacia, Universidad Nacional de Tucumán, \\ 4000 San Miguel de Tucumán, Argentina \\ ${ }^{2}$ Centro de Referencia para Lactobacilos (CERELA-CONICET), Chacabuco 145, T400OILC, San Miguel de Tucuman, \\ Argentina \\ ${ }^{3}$ Laboratorio de Investigaciones Ecológicas de las Yungas (LIEY), Facultad de Ciencia Naturales e Instituto Miguel Lillo, \\ Universidad Nacional de Tucumán, C.C. 34, 4107-Yerba Buena, Tucumán, Argentina \\ (Submitted 17 February 2012 - Final revision received 10 August 2012 - Accepted 13 August 2012 - First published online 9 November 2012)
}

\begin{abstract}
Beneficial effects of prebiotics like inulin and fructo-oligosaccharides (FOS) have been proven in health and nutrition. Yacon (Smallanthus sonchifolius), an Andean crop, contains FOS (50-70\% of its dry weight) and, therefore, is considered a prebiotic. Commercial FOS can upregulate total secretory IgA (S-IgA) in infant mice, prevent infection with Salmonella in swine or enhance immune response for Salmonella vaccine in a mouse model. Previously, we found that administration of yacon root flour regulates gut microbiota balance and has immunomodulatory effects without inflammatory responses. The aim of the present paper is to analyse if yacon prevents enteric infection caused by a strain of Salmonella enteritidis serovar Typhimurium ( $S$. Typhimurium) in a mouse model. BALB/c mice were supplemented with yacon flour ( $45 \mathrm{~d}$ ), challenged with $S$. Typhimurium and killed to study pathogen translocation, total and specific IgA production by ELISA, presence of IgA and other cytokines and Toll-like receptor 4 (TLR4) and clustor of differentiation 206 (CD206) receptors positive cells by immunofluorescence and histological changes. Yacon flour administration had a protective effect from 15 to $30 \mathrm{~d}$ of treatment. We found a peak of total S-IgA production without translocation of the pathogen for these periods. At $30 \mathrm{~d}$, there was an increase in IL- 6 and macrophage inflammatory proteins- $1 \alpha+$ cells and expression of the receptors CD206 and TLR4. Yacon flour did not have incidence in pathogen-specific S-IgA production. Longer periods ( $45 \mathrm{~d}$ ) of administration had no protective effect. Therefore, yacon can prevent enteric infection caused by $S$. Typhimurium when given up to $30 \mathrm{~d}$; this effect would be mediated by enhancing non-specific immunity, such as total S-IgA, that improves the immunological intestinal barrier.
\end{abstract}

Key words: Prebiotics: Salmonella Typhimurium infection: Mucosal immunity

In recent years, many attempts to improve quality of life have been focused on changes in feeding habits, because it is wellknown that the diet has influence on health. An example of these changes is the growing inclusion of beneficial microorganisms (probiotics) in the diet or a higher fibre intake. In this last aspect, the 'dietary fibre hypothesis' proposed that a lack of fibre in the diet has several consequences like constipation and colonic or systemic disorders (diabetes, obesity, etc. $)^{(1)}$. This concept has been evolved into the concept of prebiotics: "non-digestible food ingredients that beneficially affect the host by selectively stimulating the growth, and/or activity of beneficial bacteria in the colon and thus improve the host defense ${ }^{(2)}$, thereby expanding the range of action that the intake of these substances might have on human health. Among the beneficial effects of prebiotics, it was described that they decrease symptoms of constipation, attenuate diarrhoea symptoms and aid in immune stimulation ${ }^{(3,4)}$. As a result of the fermentation promoted by the intestinal microbiota, SCFA are released into the intestinal lumen, lowering the $\mathrm{pH}$ and restoring bacterial balance by increasing the bifidobacterial population ${ }^{(5)}$; in this sense, the prebiotics can lower the risk of colon cancer ${ }^{(6,7)}$. Other properties attributed to

\footnotetext{
Abbreviations: B, basal; CFU, colony-forming units; dPC, days post-challenge; FOS, fructo-oligosaccharide; IC, infection control; IFN, interferon; MIP macrophage inflammatory protein; NC, normal control; SI, small-intestine; SIF, small-intestinal fluid; S-IgA, secretory IgA; ST, Salmonella Typhimurium; TG, treated group; TLR4, Toll-like receptor 4
} 
prebiotics are reduction of the incidence of osteoporosis by increasing $\mathrm{Ca}$ bioavailability and better mineral absorption ${ }^{(8)}$ and also diminishing the level of LDL-cholesterol and lipids in serum in animals and human subjects $(9,10)$

The most common food ingredients included in this category are $\beta$-1,2-fructans-type oligosaccharides like inulin (fructosylfructose linkages with a terminal glucose and a polymerisation degree 2-60) and fructo-oligosaccharides (FOS; same type of linkages with a terminal glucose or fructose and a polymerisation degree $2-8)^{(11)}$ and, to a lesser extent, xylo-oligosaccharides, galacto-oligosaccharides, soyabeanoligosaccharides, etc. ${ }^{(12)}$.These non-digestible oligosaccharides naturally occur in plants like garlic, onions, chicory and others ${ }^{(13,14)}$; they also are commercially produced in industry by partial enzymatic hydrolysis or enzymatic synthesis using transfructosyl activity of $\beta$-fructosidase $e^{(12,15)}$.

There are many sources of oligofructans, one of these is the root from the Andean crop yacon (Smallanthus sonchifolius). Yacon root is a tuber; in the fresh state, it contains $83-86 \%$ of water and $10-12 \%$ of FOS, which represents $50-70 \%$ of its dry weight ${ }^{(16)}$. This plant also contains proteins (0.4-2\%), minerals ( $\mathrm{K}, \mathrm{Ca}, \mathrm{Fe}, \mathrm{P}, \mathrm{Zn}$ and $\mathrm{Mg}$ ), vitamins (B and $\mathrm{C}$ ) and it is very rich in secondary metabolites like phenolic compounds and antioxidants ${ }^{(16-18)}$. However, the most important point that makes it a plant of interest is the high content of FOS, because of which it could be considered a prebiotic.

In South America, yacon root is consumed as a fruit and it grows from Venezuela to the north of Argentina. Originally, the roots and leaves were used in folkloric medicine by aboriginal people and recently it was exported to the European market as a functional food ${ }^{(19)}$. Nowadays, yacon is a plant with a growing use as a dietary supplement. It has several proven beneficial properties that coincide with those described before for commercial prebiotics. In particular, the leaves have a positive effect in sugar metabolism ${ }^{(20)}$, and the phenolic compounds extracted from them have antioxidant ${ }^{(21)}$ and also antifungal activity ${ }^{(22)}$. Intake of roots can prevent metabolic disorders, especially those related to the development of type 2 diabetes, and it can also reduce TAG and cholesterol levels in serum ${ }^{(23)}$. Yacon roots have laxative properties ${ }^{(24)}$ and they are used as natural sweeteners; its consumption does not produce negative effects in human subjects or animals ${ }^{(25)}$.

Studies with commercial FOS have proposed that its administration may regulate secretion of total secretory $\operatorname{IgA}(\mathrm{S}-\operatorname{IgA})$ in infant rats ${ }^{(26)}$, and it could be a more effective treatment to prevent Salmonella Typhimurium (ST) infection in swine $^{(27)}$ or to enhance ST vaccine in a mice model ${ }^{(28)}$. Another study showed that administration of inulin may protect against liver damage when mice are challenged with pathogens preventing translocation ${ }^{(29)}$.
In addition to these properties, in our previous work, we found that yacon root flour, when administered for a long period of time, increases the number of bifidobacteria and lactobacilli in the large intestine and has gut-immunomodulatory effects in a mouse model. Its administration provoked an increase of IgA + cells and other cytokines. It also activated $\mathrm{T}$ cells and induced production of IL-10, interferon (IFN)- $\gamma$ and IL- $4+$ cells. Yacon administration showed the capacity to maintain intestinal homeostasis without inducing inflammatory responses ${ }^{(30)}$

Salmonella Typhi and Paratyphi are human-restricted pathogens, while ST is restricted to mice. It is well-known that ST develops infection in BALB/C mice in a comparable way to that of typhoid fever in human subjects; thus, the mouse model treated with this bacterial strain has been very useful in assessing mechanism of infection and possible new treatments to counteract or prevent the progression of an infection caused by this pathogen ${ }^{(31-34)}$.

The aim of the present study was to analyse if the FOS from yacon root flour can prevent enteric infection caused by the pathogen Salmonella enterica serovar Typhimurium (ST) and to elucidate some possible mechanisms involved in such protection in a mouse model, this being a relevant approach to design non-invasive treatments in the prevention of enteric infections in human health.

\section{Materials and methods}

\section{Experimental animals}

Male BALB/c mice (aged 6 weeks), weighing 25 (sem 1) g, were obtained from a closed random breeding colony, maintained at the Institute of Microbiology Luis C. Verna (Facultad de Bioquimíca, Química y Farmacia - Universidad Nacional de Tucumán). Mice were kept in separate cages with a controlled atmosphere $\left(18 \pm 2^{\circ} \mathrm{C}\right.$ and $12 \mathrm{~h}$ dark-12 h light cycle) and fed with a solid conventional diet and water ad libitum. Animals were randomly divided into four groups: normal control (NC) group (conventional diet + water), basal (B) group (conventional diet + yacon root flour + water), infection control (IC) group (conventional diet + water and challenge with ST) and treated group (TG, conventional diet + yacon root flour + water + ST) (Fig. 1). In order to obtain reproducible results, three different trials were performed with a total of eighty-four animals for each individual trial, which were divided as follows: six mice for the NC group, six for the $\mathrm{B}$ group, thirty-six mice for the IC group and thirty-six mice for the TG group. Sample size corresponded to six mice for each determination.

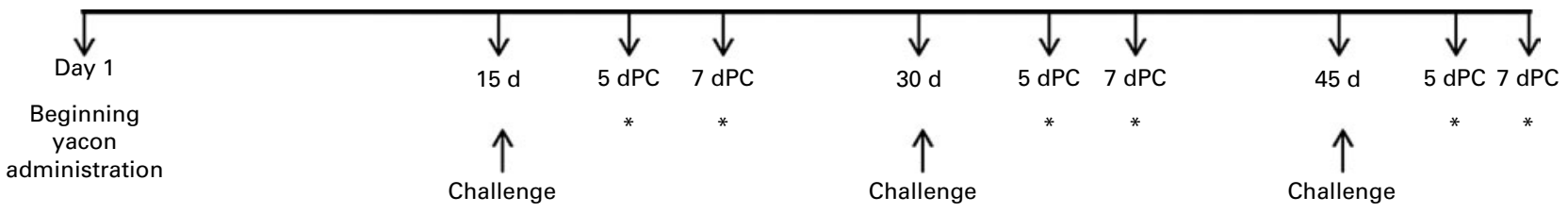

Fig. 1. Yacon administration scheme. Yacon was administered for forty-five consecutive days. For in vivo and ex vivo assays, samples were taken at 15,30 and $45 \mathrm{~d}$ (basal group). For the infection control group, mice were challenged with Salmonella Typhimurium. The treated group was also challenged at the same period. Treated and untreated mice were killed at 5 and $7 \mathrm{~d}$ post-challenge (dPC). * Kill. 
All animal protocols and trials mentioned in the present paper complied with the present laws of Argentina and were approved by the Ethical committee from the Instituto de Microbiología Luis C. Verna and the board of the Facultad de Bioquimíca, Química y Farmacia - Universidad Nacional de Tucumán.

\section{Collection of intestinal fluids}

Samples of intestinal fluids were collected at 15, 30 and $45 \mathrm{~d}$ of yacon root flour administration for the ex vivo studies and at 5 and $7 \mathrm{~d}$ post-challenge (dPC) after ST challenge in $1 \mathrm{ml}$ of $0.01 \mathrm{M}-\mathrm{PBS}$. For all procedures, small intestines (SI) were placed in sterile Petri dishes, $1 \mathrm{ml}$ of PBS was passed through it and the contents were collected in tubes and centrifuged at $5000 \mathrm{~g}$ for $15 \mathrm{~min}$ at $4^{\circ} \mathrm{C}$, maintaining sterile conditions. Supernatants were stored at $-18^{\circ} \mathrm{C}$ until further determinations.

\section{Ex vivo assay - determination of antimicrobial substances in the intestinal lumen}

Yacon was given by oral administration to 6-week-old male $\mathrm{BALB} / \mathrm{c}$ mice for forty-five consecutive days $(340 \mathrm{mg} / \mathrm{kg}$ per $\mathrm{d}$ - approximately $8.5 \mathrm{mg}$ of yacon root flour resuspended into $200 \mu \mathrm{l}$ of water per mouse). Mice were then killed at different time points, i.e. at 15,30 and $45 \mathrm{~d}$ of administration. These periods were previously determined as optimal to stimulate mucosal immunity ${ }^{(30)}$. The small-intestinal fluids (SIF) were collected and used to determine the appearance of inhibition halos when ST is grown in its presence. Each SIF was filtered and divided in two parts, one part was used in normal conditions and the other was added along with $\mathrm{CO}_{3}{ }^{2-} / \mathrm{HCO}_{3}{ }^{1-}$ buffer $(\mathrm{pH} 9.5)$ to neutralise the $\mathrm{pH}$ in order to avoid any effect mediated by the acidic conditions of the SIF. The agar diffusion method was used in the present study. ST was grown in Müeller Hinton agar containing the SIF and plated in two different dilutions $(0 \cdot 1$ and $0.2 \mathrm{ml}$ of a suspension of the pathogen, with a concentration of $1 \times 10^{8}$ colony-forming units $(\mathrm{CFU}) / \mathrm{ml}$, in $22 \mathrm{ml}$ Müeller Hinton agar at $45-50^{\circ} \mathrm{C}$ ). Aliquots of $50 \mu \mathrm{l}$ of each fluid (neutralised and non-neutralised) were added into $4 \mathrm{~mm}$ diameter wells punched in the solidified medium. Antimicrobial activity was visualised qualitatively through the appearance of an inhibition halo on the plates after $24 \mathrm{~h}$ of incubation at $37^{\circ} \mathrm{C}$. SIF from normal mice without yacon root flour administration were used as a negative control.

\section{Yacon root flour administration and challenge with the pathogen}

Mice from B and TG groups, fed with conventional diet, were supplemented with FOS from the yacon root flour (340 mg/kg per d) for forty-five consecutive days by oral $\operatorname{administration}^{(30)}$.

The ST strain was isolated from faeces of children from the Hospital del Niño Jesus and provided by the Bacteriology Laboratory of the Microbiology Institute (Facultad de Bioquimíca, Química y Farmacia-Universidad Nacional de Tucumán). A measure of $200 \mu \mathrm{l}$ of ST overnight culture was placed in $5 \mathrm{ml}$ of fresh $\mathrm{BHI}$ broth, incubated for $4 \mathrm{~h}$ and adjusted to a concentration of $1 \times 10^{8} \mathrm{CFU} / \mathrm{ml}$. Mice were challenged at 15 , 30 and $45 \mathrm{~d}$ of yacon root flour administration, with $100 \mu \mathrm{l}$ of the pathogen suspension $\left(\mathrm{DL}_{50}\right)$ by oral administration ${ }^{(35)}$. At 5 and $7 \mathrm{dPC}$, animals were killed. The SI, liver and spleen tissues were removed and the intestinal fluid was collected.

\section{Colonisation assay}

The present study was conducted to determine if yacon root flour administration prevents ST translocation to the deep tissues. Liver and spleen from TG and IC groups were aseptically removed, weighed and collected into sterile tubes containing $5 \mathrm{ml}$ of peptone water $(0 \cdot 1 \%)$. The samples were homogenised using microhomogeniser (MSE) while maintaining sterile conditions. Serial dilutions were made in peptone water and the selected dilutions were spread on MacConkey agar. Plates were incubated aerobically at $37^{\circ} \mathrm{C}$ for $18 \mathrm{~h}$. Results were expressed as log CFU per $g$ of organ.

\section{Total and specific secretory IgA determination in small- intestinal fluid}

To measure the total S-IgA levels at 15, 30 and $45 \mathrm{~d}$ after yacon root administration and at 5 and $7 \mathrm{dPC}$, an ELISA test was performed according to the technique described previously ${ }^{(36)}$. Briefly, Costar ninety-six-well microplates (Corning, Inc.) were coated with goat anti-mouse IgA affinity-purified antibody (BETHYL Laboratories, Inc.) diluted in $0.05 \mathrm{M}$-carbonate-bicarbonate buffer ( $\mathrm{pH} 9.6$ ) and incubated for $1 \mathrm{~h}$ at $37^{\circ} \mathrm{C}$. Then, the plates were washed with $0.05 \%$ PBS-Tween 20 and blocked for $1 \mathrm{~h}$ using $0.5 \%$ non-fat dry milk resuspended in PBS. Plates were washed with PBS-Tween 20 and incubated for $2 \mathrm{~h}$ at $37^{\circ} \mathrm{C}$ with $50 \mu \mathrm{l}$ of either diluted samples or standard kappa IgA (Sigma). Plates were washed again and coated with horseradish peroxidase-conjugated anti-IgA-specific antibodies (Sigma) for $1 \mathrm{~h}$ at $37^{\circ} \mathrm{C}$. Finally, plates were washed and incubated with trimethylbenzidine reagent containing peroxide (BD Bio-sciences) and the reaction was stopped using $2 \mathrm{M}-\mathrm{H}_{2} \mathrm{SO}_{4}$. The optical density was read at $450 \mathrm{~nm}$ using a VERSA Max Microplate reader (Molecular Devices). Results were expressed as concentration of S-IgA $(\mu \mathrm{g} / \mathrm{ml})$ in intestinal fluids.

To measure specific anti-ST S-IgA, plates were coated with $50 \mu \mathrm{l}$ of a concentrated heat-inactivated suspension of ST $\left(10^{10}\right.$ $\mathrm{CFU} / \mathrm{ml}$ ) and incubated overnight at $4^{\circ} \mathrm{C}$. Then, the plates were blocked and the technique was performed as described earlier. Results were expressed as optical density at $450 \mathrm{~nm}$.

\section{Histological studies and determination of IgA+ cells - direct immunofluorescence}

The SI were removed, washed with $0 \cdot 01 \mathrm{M}-\mathrm{PBS}$, cut into small pieces and used for histological preparations according to the technique described by Sainte-Marie ${ }^{(37)}$. Paraffin blocks were maintained at $4^{\circ} \mathrm{C}$ until use. Serial paraffin sections $(4 \mu \mathrm{m})$ were cut and haematoxylin-eosin staining was performed for light microscopy examination. 
An immunofluorescence assay was used to determine IgA+ cells in the SI. After deparaffinisation using xylene and rehydration in a decreasing gradient of ethanol, paraffin sections $(4 \mu \mathrm{m})$ were incubated with a dilution of $\alpha$-chain mono-specific antibody conjugated with fluorescien isothiocyanate (Sigma) for $30 \mathrm{~min}$ and observed with a fluorescent light microscope. The number of fluorescent cells was counted in thirty fields of vision at $1000 \times$ magnification. Results were expressed as the number of fluorescent cells per ten fields of view.

\section{Cytokines and receptors positive cells expression - indirect immunofluorescence assay}

Tissue sections $(4 \mu \mathrm{m})$ of SI from each mouse were obtained as described earlier. Cytokines (IL-6, IFN- $\gamma$, TNF- $\alpha$ and macrophage inflammatory protein (MIP)-1 $\alpha$ )- and receptors Toll-like receptor 4 (TLR4) and clustor of differentiation 206 (CD206)expressing cells were detected by indirect immunofluorescence assay following the technique described by Galdeano \& Perdigon ${ }^{(38)}$. After deparaffinisation and rehydration, tissue sections were incubated with a blocking solution of $1 \%$ bovine serum albumin (BSA) in PBS for $30 \mathrm{~min}$ at room temperature and washed three times in PBS. For the detection of IL-6-, IFN- $\gamma$-, TNF- $\alpha$ - and MIP- $1 \alpha$-positive cells, rabbit antimouse polyclonal antibodies (Peprotech, Inc. and ProSci Incorporated, respectively) were diluted in saponin-PBS and applied. To detect TLR4- and CD206-expressing cells, rat anti-mouse monoclonal TLR4 (eBioscience, Inc.) and mouse anti-human monoclonal antibody (BD Bioscience) were diluted in PBS and used. All the antibodies were incubated for $105 \mathrm{~min}$ at room temperature $\left(25^{\circ} \mathrm{C}\right)$. The slides were washed twice with PBS and incubated for $60 \mathrm{~min}$ at room temperature with a dilution of fluorescien isothiocyanate-conjugated goat anti-rabbit, goat anti-rat and goat anti-mouse antibodies, respectively (Jackson Immuno Research Labs, Inc.). Positive cells were counted in thirty fields of vision and expressed as the number of fluorescent cells per ten fields at $1000 \times$ magnification.

\section{Statistical analysis}

All the results presented in the present article are means of three independent trials with their standard errors. For the microbiological and immunological studies, statistical analysis was performed using MINITAB 15 software (Minitab, Inc.) by general linear model ANOVA followed by Tukey's post hoc test, and $P \leq 0.05$ was considered as significant. Student's $t$ test was used to assess the statistical significance of the differences between the treated and the control groups for the histological studies.

\section{Results}

Induction of the antimicrobial substances released in the intestinal lumen - ex vivo assay

The present ex vivo assay was performed to verify whether the administration of yacon root flour induces the release or the production of antimicrobial substances (different from
S-IgA) in the intestinal lumen as a consequence of the yacon influence on the metabolism of the local microbiota.

When the ex vivo assay was performed, we did not find inhibition halos in any of the periods of administration studied $(15,30$ and $45 \mathrm{~d})$, and in the non-neutralised as well as in the neutralised SIF, the results were negative; due to this fact these results are not shown.

\section{Study of Salmonella Typhimurium translocation to liver and spleen - in vivo assay}

To study the effect of yacon root in preventing enteric infection, we analysed if its administration had the ability to inhibit or at least reduce pathogen translocation to deep tissues such as the liver and spleen.

In general, we observed significant differences in the colonisation extent in some of the time points studied. In liver, for $15 \mathrm{~d}$ of yacon root flour administration and $7 \mathrm{dPC}$,
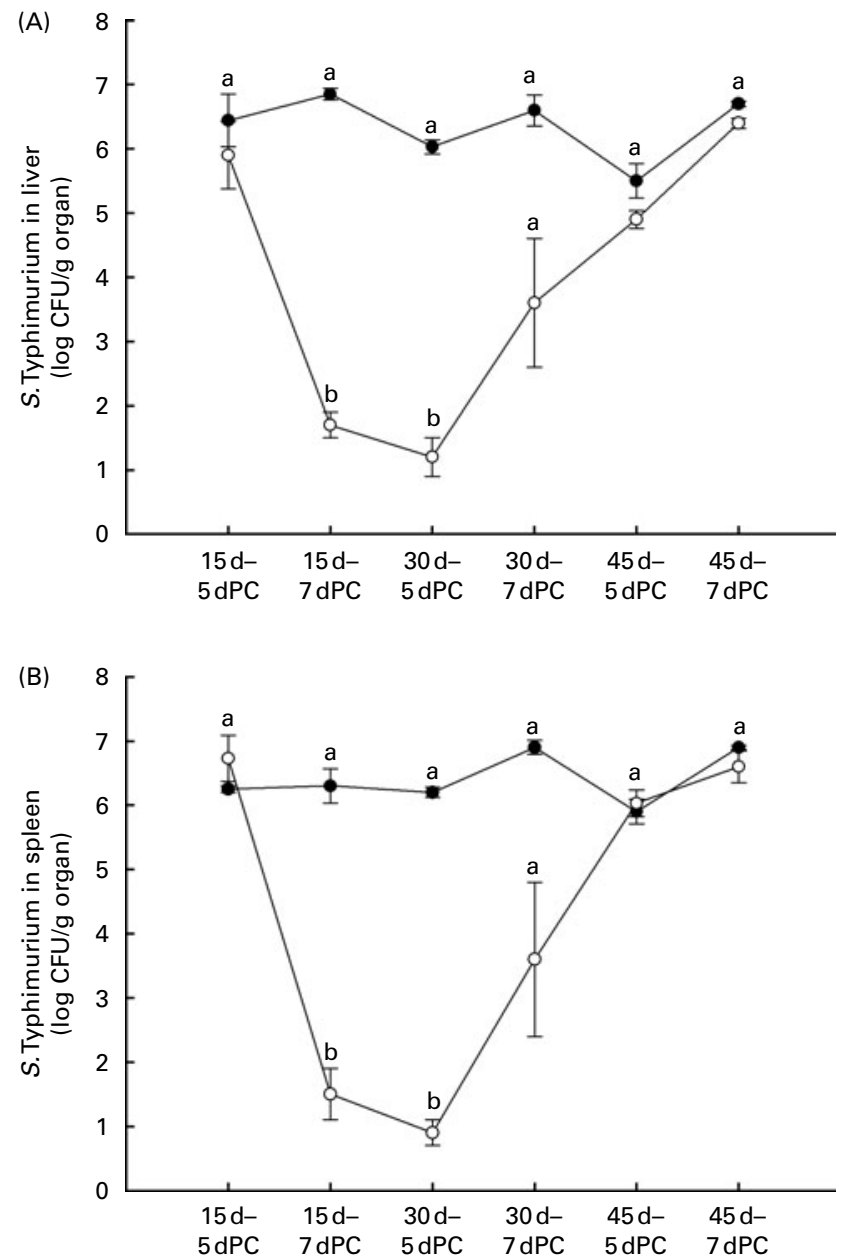

Fig. 2. Translocation of Salmonella Typhimurium to (A) liver and (B) spleen. Data correspond to treated ( $-0-$, treated group) and non-treated ( - infection control) mice with yacon root flour. Colonisation of $S$. Typhimurium in liver and spleen is expressed as $\log _{10}$ number of bacteria/g of each organ. Values are means ( $n 6)$, with their standard errors represented by vertical bars for 15,30 and $45 \mathrm{~d}$ of yacon root administration and for 5 and $7 \mathrm{~d}$ postchallenge ( $\mathrm{dPC})$, from three different trials. ${ }^{\mathrm{a}, \mathrm{b}}$ Mean values with unlike letters were significantly different $(P \leq 0.05)$. CFU, colony-forming units. 
Table 1. Levels of total secretory $\lg A(S-\lg A)$ in small-intestinal fluids $(\mu \mathrm{g} / \mathrm{ml})$ induced by yacon root flour administration in basal samples (prior to Salmonella Typhimurium infection)*

(Mean values with their standard errors, $n 6$ animals from three independent experiments)

\begin{tabular}{|c|c|c|c|c|c|c|}
\hline \multirow{2}{*}{$\begin{array}{l}\text { Period... } \\
\text { Group }\end{array}$} & \multicolumn{2}{|c|}{$15 d$} & \multicolumn{2}{|c|}{$30 \mathrm{~d}$} & \multicolumn{2}{|c|}{$45 d$} \\
\hline & Mean & SEM & Mean & SEM & Mean & SEM \\
\hline $\mathrm{NC}$ & $81 \cdot 1^{\mathrm{a}}$ & 1.30 & $80 \cdot 1^{a}$ & 1.50 & $81 \cdot 2^{\mathrm{a}}$ & 1.20 \\
\hline B & $176 \cdot 0^{b}$ & $8 \cdot 30$ & $117 \cdot 0^{c}$ & 7.90 & $106 \cdot 0^{c}$ & $8 \cdot 10$ \\
\hline
\end{tabular}

NC, normal control; B, basal.

$\mathrm{a}, \mathrm{b}, \mathrm{c}$ Mean values with unlike letters were significantly different $(P \leq 0.05)$.

* Total S-IgA from intestinal fluid of NC and B groups was measured by an ELISA test. Samples were taken at 15,30 and $45 \mathrm{~d}$ of yacon root flour intake without infection with $S$. Typhimurium ${ }^{(30)}$.

we found a significant decrease of ST translocation in the TG compared with the IC group. For $30 \mathrm{~d}$ of treatment, we had the highest differences between the TG and the IC groups, where the TG group showed significantly decreased levels of translocation and had a higher protective effect for 5 and $7 \mathrm{dPC}$ when compared with the IC group. At $45 \mathrm{~d}$ (end of study), the yacon supplementation did not prevent the dissemination of ST, neither at 5 nor at $7 \mathrm{dPC}$. These results are expressed in Fig. 2(A) $(P \leq 0.05)$

The colonisation assay in the spleen presented similar results to those found in liver. At $15 \mathrm{~d}$, yacon flour administration significantly decreased pathogen counts in the TG group at $7 \mathrm{dPC}$ compared to the IC group. For $30 \mathrm{~d}$, yacon root supplementation had the best protective effect against ST infection, showing a significant decrease of pathogen counts in the TG group when compared with the IC group for 5 and $7 \mathrm{dPC}$. In the group administered with yacon flour for $45 \mathrm{~d}$, no protective effect was observed (Fig. 2(B)) $(P \leq 0 \cdot 05)$

Influence of the yacon root flour on the production of total and specific secretory IgA in fluids from the small intestine in treated and challenged mice

Table 1 shows the values obtained for total S-IgA after 15, 30 and $45 \mathrm{~d}$ of yacon root administration. After 5 and $7 \mathrm{dPC}$ with ST, there was a significant increase in the levels of total S-IgA only in the group treated with yacon flour for $30 \mathrm{~d}$. Values for 15 and $45 \mathrm{~d}$ of feeding with the yacon root were similar to those for the IC group; the minimum level of total S-IgA for the TG group was found at $45 \mathrm{~d}$ and no protection against Salmonella was observed (Table 2$)(P \leq 0 \cdot 05)$.

When studying the production of anti-ST S-IgA after challenge, we found that yacon flour had no influence on this variable. Values for the TG group were low and had no significant difference compared with the IC group during the study; only a slight increase of specific S-IgA was observed in the TG group at $45 \mathrm{~d}$ of treatment and at $5 \mathrm{dPC}$ (Fig. 3).

\section{Influence of yacon root flour administration on the histological architecture of the intestine}

We analysed if the administration of yacon root flour had an effect on the histological structure of the SI using the haematoxylin-eosin staining technique for $30 \mathrm{~d}$ of yacon root administration and for $7 \mathrm{dPC}$. Diet supplementation with yacon in the basal group ( $30 \mathrm{~d}$ of consumption) increased cellularity in the lamina propria of the SI, but did not alter the normal architecture compared with the NC group (Fig. 4(A), (B)). This same effect was observed in the treated and the challenged group (TG, $7 \mathrm{dPC}$ ) (Fig. $4(\mathrm{C})$ ). The infection control showed an altered villous architecture as a result of the inflammation caused by the pathogen (Fig. 4(D)). At $15 \mathrm{~d}$, histological studies of samples obtained at $7 \mathrm{dPC}$ were similar to those obtained at $30 \mathrm{~d}$. For $45 \mathrm{~d}$ of yacon root flour consumption and $7 \mathrm{dPC}$, histological studies in the TG group were similar to the IC group (data not shown).

\section{Influence of yacon root flour intake on IgA+ cells in lamina propria of small intestine}

In a previous study, we determined an increase in the IgA+ cells present in lamina propria of the SI for 30 and $45 \mathrm{~d}$ of administration (basal: 98 (SEM 8) and 160 (SEM 5) positive cells for 30 and $45 \mathrm{~d}$ of administration, respectively) ${ }^{(30)}$. Considering these facts, in the present work, we determined the IgA-producing cells after ST challenge. We observed that for $7 \mathrm{dPC}$, at 30 and $45 \mathrm{~d}$ of consumption, the IgA + cells in the SI showed a large increase in the treated and infected groups and in the infected and basal groups compared with the normal controls. No difference between all the challenged groups was found (Fig. 5) $(P \leq 0 \cdot 05)$.

Table 2. Total secretory IgA (S-IgA) concentration in small-intestinal fluids $(\mu \mathrm{g} / \mathrm{ml})$ induced by yacon root flour administration after being challenged with Salmonella Typhimurium*

(Mean values with their standard errors, $n 6$ animals from three different experiments)

\begin{tabular}{|c|c|c|c|c|c|c|c|c|c|c|c|c|}
\hline \multirow{3}{*}{$\begin{array}{l}\text { Period... } \\
\text { Group }\end{array}$} & \multicolumn{4}{|c|}{$15 d$} & \multicolumn{4}{|c|}{$30 \mathrm{~d}$} & \multicolumn{4}{|c|}{$45 d$} \\
\hline & \multicolumn{2}{|c|}{$5 \mathrm{dPC}$} & \multicolumn{2}{|c|}{$7 \mathrm{dPC}$} & \multicolumn{2}{|c|}{$5 \mathrm{dPC}$} & \multicolumn{2}{|c|}{$7 \mathrm{dPC}$} & \multicolumn{2}{|c|}{$5 \mathrm{dPC}$} & \multicolumn{2}{|c|}{$7 \mathrm{dPC}$} \\
\hline & Mean & $\overline{\text { SEM }}$ & Mean & $\overline{\text { SEM }}$ & Mean & $\overline{\text { SEM }}$ & Mean & $\overline{\text { SEM }}$ & Mean & $\overline{\text { SEM }}$ & Mean & $\overline{\text { SEM }}$ \\
\hline IC & $39.6^{a}$ & 4.51 & $20.9^{b}$ & 1.52 & $8.79^{c}$ & 1.28 & $6 \cdot 24^{\mathrm{C}}$ & $2 \cdot 22$ & $24 \cdot 7^{\mathrm{a}, \mathrm{b}}$ & $5 \cdot 35$ & $14 \cdot 1^{\mathrm{e}}$ & 0.62 \\
\hline TG & $38 \cdot 3^{a}$ & 10.3 & $23 \cdot 4^{\mathrm{b}}$ & 1.40 & $35 \cdot 6^{\mathrm{a}}$ & 0.81 & $13 \cdot 8^{\mathrm{d}, \mathrm{e}}$ & 2.01 & $16 \cdot 3^{d}$ & 0.97 & $12 \cdot 1^{\mathrm{e}}$ & 5.41 \\
\hline
\end{tabular}

$\mathrm{dPC}$, days post-challenge; IC, infection control; TG, treated group.

a,b,c,d,e Mean values with unlike letters were significantly different $(P \leq 0.05)$

* Total S-IgA of small intestinal fluids from IC and TG post-infection was measured by ELISA. Time points were 15, 30 and $45 \mathrm{~d}$ of administration (basal) 5 and $7 \mathrm{dPC}$. Results are expressed as concentration of S-lgA $(\mu \mathrm{g} / \mathrm{ml})$. 


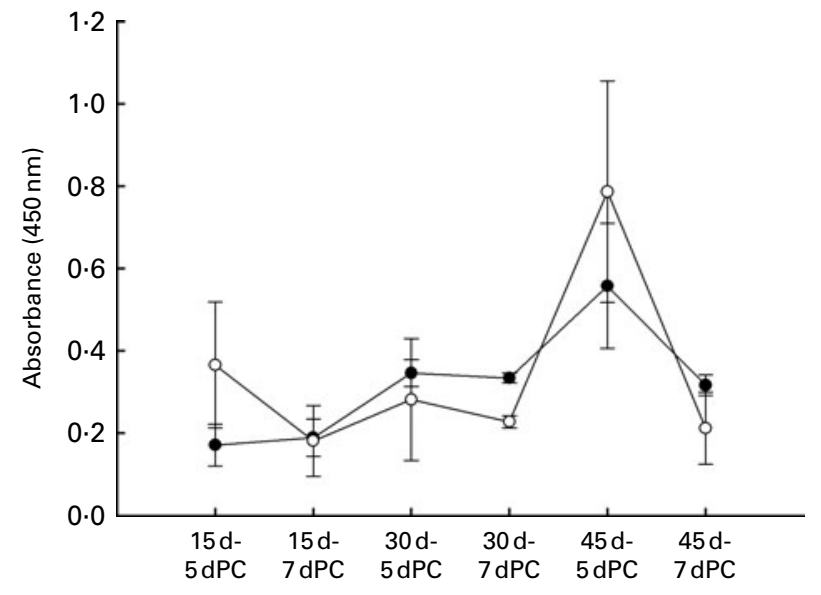

Fig. 3. Levels of specific secretory $\lg A(S-\lg A)$ in small-intestinal fluid from treated $(-\circ-$, treated group) and non-treated $(-\bullet-$, infection control) challenged mice. Specific S-IgA of small-intestinal fluids from challenged mice was measured by ELISA. Time points were 15,30 and $45 d$ and 5 and $7 d$ post-challenge (dPC). Results are expressed as level of absorbance (optical density at $450 \mathrm{~nm}$ ). Values are means of $n 6$ animals from three different experiments, with their standard errors represented by vertical bars.

\section{Influence of yacon root flour administration on cytokine} production and in the receptor expression of positive immune cells associated with the lamina propria of the small intestine

In order to establish other parameters of cellular activation that might be involved in a protective effect exerted by yacon root flour against ST infection, we determined the expression of some cytokines such as IL- 6 , TNF- $\alpha$ IFN- $\gamma$ and the chemokine MIP- $1 \alpha$ and receptors such as TLR 4 and
CD206 from the innate immune cells by indirect immunofluorescence.

The cytokines analysed showed that IL- $6+$ cells, which induce maturation of $\mathrm{B}$ cells, increased in the TG group over the normal control and the IC group. The number of IFN- $\gamma+$ and TNF- $\alpha+$ cells was higher in the basal and the TG groups compared with the NC group; however, the TG group had no difference compared with the infection control and MIP- $1 \alpha+$ cells were augmented after yacon root intake (basal point B) in the TG group compared with the NC group, without significant difference with the IC group (Table 3) $(P \leq 0.05)$

With regard to TLR4 and CD206 receptors, we found a similar behaviour to those found for the chemokine MIP- $1 \alpha+$ cells. The B group and the TG group had a greater number of TLR 4 and CD206+ cells compared with the NC group. The TG group was also higher than the IC group (Table 3).

\section{Discussion}

We demonstrated that yacon root did not exert antimicrobial activity against ST by ex vivo assay; even the prolonged administration of yacon ( $45 \mathrm{~d}$ ) did not induce the production of molecules with antimicrobial activity.

In a previous study, total S-IgA was measured after yacon root administration in basal samples at the end of each period (15,30 and $45 \mathrm{~d}$ of treatment) prior to ST challenge. We observed a remarkable increase of antibody at $15 \mathrm{~d}$ of yacon administration compared with the normal control, and only a slight increase at 30 and $45 \mathrm{~d}$ also compared with the normal control (Table 1$)^{(30)}$. In the present work, the major
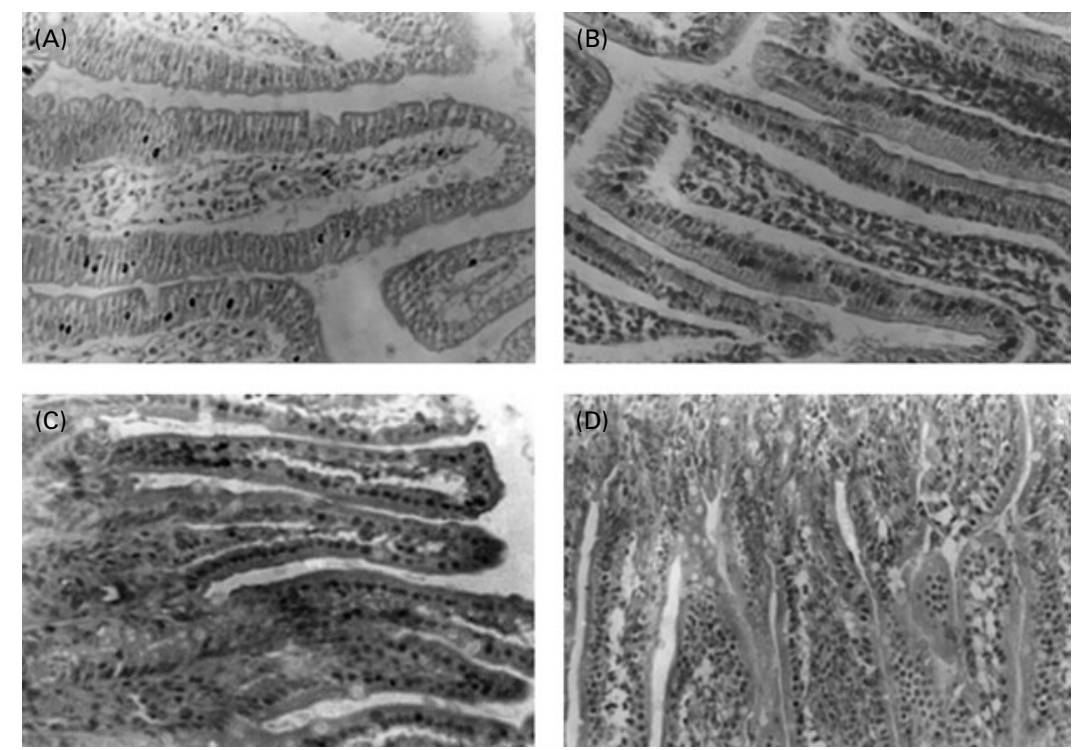

Fig. 4. Histological study of small intestine for $30 \mathrm{~d}$ of yacon root flour administration. Tissue sections of small intestine were stained with haematoxylin-eosin. Images belong to (A) normal control; (B) basal samples ( $30 \mathrm{~d}$ of yacon root flour administration); (C) treated group, treated with $30 \mathrm{~d}$ of yacon root flour and at $7 \mathrm{~d}$ post-challenge (dPC); and (D) infection control ( $7 \mathrm{dPC})$. The B and the TG groups maintain unaltered structure of tissue with increased cellularity compared to the NC group, while the IC group shows damaged architecture because of the infection caused by Salmonella Typhimurium. The histological study for $15 \mathrm{~d}$ was similar to that for $30 \mathrm{~d}$ of yacon root administration; for $45 \mathrm{~d}$, the histology of the small intestine was similar to the IC group (data not shown). Images were taken at $1000 \times$ magnification. 

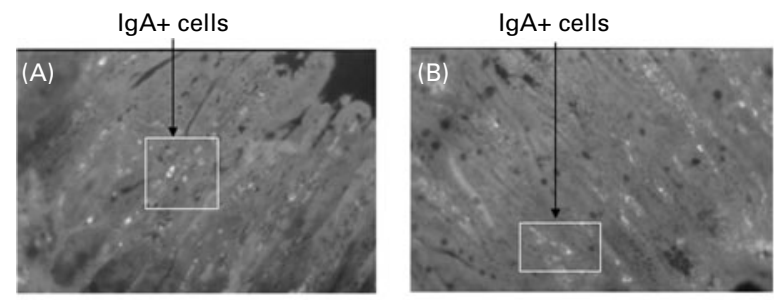

(C)

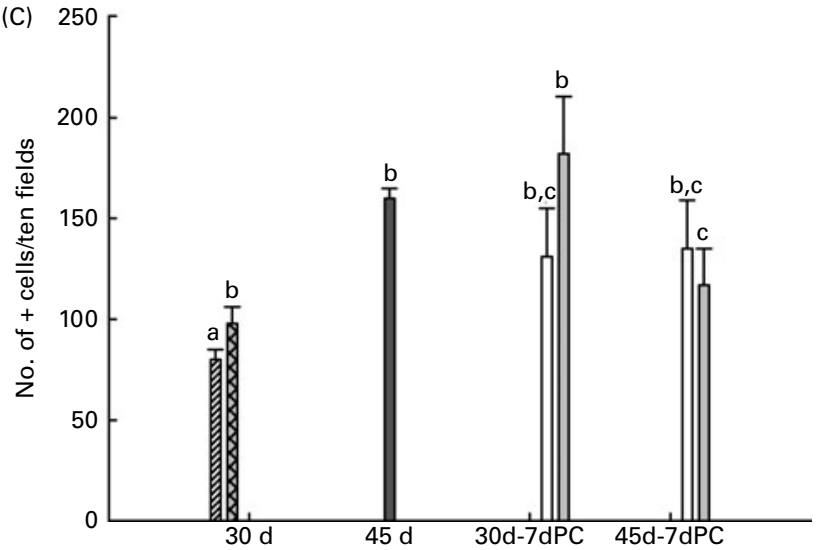

Fig. 5. IgA + cells counts in lamina propria of small intestine. (A, B) Pictures of IgA + cells for infection control (IC) and treated group (TG) groups, respectively. IgA + cells were counted by direct immunofluorescence in tissue sections of small intestine at 30 and $45 \mathrm{~d}$ of yacon root flour consumption after $7 \mathrm{~d}$ post-challenge (dPC). (C) Values are means $(n 6)$, with their standard errors represented by vertical bars for total cells counted for every ten fields at $1000 \times$ magnification. Although administration of yacon root flour increased the number on IgA + cells in basal samples, no differences were observed in the TG after Salmonella Typhimurium challenge $(7 \mathrm{dPC})$ in relation to the IC group $(P \leq 0.05)$. ${ }^{\mathrm{a}, \mathrm{b}, \mathrm{c}}$ Mean values with unlike letters were significantly different $(P \leq 0.05)$. 四, Normal control; 图, basal $30 \mathrm{~d} ; \square$, basal $45 \mathrm{~d} ; \mathrm{\square}, \mathrm{IC} ; \mathrm{\square}, \mathrm{TG}$.

protection against Salmonella was found at $30 \mathrm{~d}$ of yacon root administration. This effect could be due to the high number of IgA-producing cells and the total S-IgA released in the intestinal lumen, determined before and post-infection for this period of time. However, only a slight production of specific S-IgA was determined in this period of administration (Table 2; Fig. 3). These results indicate that protection exerted by yacon root flour administration against the pathogen assayed would be mediated by non-specific immunity (total S-IgA) more than the specific S-IgA. Total S-IgA would avoid the internalisation of the pathogen and the immune complexes would be eliminated through peristalsis, as it was described by Lamm et $a l^{(39)}$

For $15 \mathrm{~d}$ of treatment, even when there is a high level of total S-IgA at $5 \mathrm{dPC}$, translocation of ST was not controlled. However, the protection found at $7 \mathrm{dPC}$ could be due to the decrease of this Ig, in which the values were similar to the infection control (Table 2), the Ig could have neutralised the pathogen in the intestinal lumen preventing its translocation to liver and spleen.

Results for $45 \mathrm{~d}$ of diet supplementation with yacon root flour showed no protective effect against ST infection. The slight increase obtained in total S-IgA was not enough to neutralise pathogen internalisation. The effect was not remarkable for specific IgA for any period of yacon administration assayed, where specific anti-ST S-IgA levels did not show difference with the IC group.

After $30 \mathrm{~d}$ of yacon administration, we observed an increase in B lymphocytes, leading to increase in the number of IgA-producing cells in the lamina propria of SI and the total S-IgA. These increases could be a consequence of the stimulation caused by the FOS contained in the yacon root that would stimulate LB lymphocytes from the lamina propria of the SI and the IgA present in the surface of B cells. However, for $45 \mathrm{~d}$ of administration, although the number of IgA + cells was high (Fig. 5), no protective effect was observed (Fig. 2). We believe that the lack of protection for $45 \mathrm{~d}$ was due to the diminution in the level of total S-IgA, even when the $\mathrm{IgA}+$ cells were enhanced, and also to the inflammatory profile induced after $45 \mathrm{~d}$ of yacon administration, with an increase of IFN- $\boldsymbol{\gamma}$ that was not regulated by IL-10, as it was demonstrated in previous paper ${ }^{(30)}$, and by the infiltration observed in histological studies in this time point of yacon root administration after $7 \mathrm{dPC}$. The present findings led us to conclude that the simple increase of $\operatorname{IgA}+$ cells in the lamina propria of the SI is not the only predictive variable to be considered in the protection of prebiotics against an enteric infection

We demonstrated that yacon root flour intake for 15 and $30 \mathrm{~d}$ after $7 \mathrm{dPC}$ improve the histological alterations induced by the pathogen, the effect being more remarkable for $30 \mathrm{~d}$ with regards to $7 \mathrm{dPC}$ of the IC mice (Fig. 4). For $45 \mathrm{~d}$ of

Table 3. Cytokine-expressing cells and receptor-expressing cells from lamina propria of small intestine, pre- and post-challenge, in treated and untreated groups ${ }^{\star} \dagger$

(Mean values with their standard errors, $n 6$ )

\begin{tabular}{|c|c|c|c|c|c|c|c|c|c|c|c|c|}
\hline \multirow[b]{2}{*}{ Experimental groups } & \multicolumn{2}{|c|}{ IL-6 } & \multicolumn{2}{|c|}{ IFN- $\gamma$} & \multicolumn{2}{|c|}{ TNF- $\alpha$} & \multicolumn{2}{|c|}{ MIP- $1 \alpha$} & \multicolumn{2}{|c|}{ TLR-4 } & \multicolumn{2}{|c|}{ CD206 } \\
\hline & Mean & SEM & Mean & SEM & Mean & SEM & Mean & SEM & Mean & SEM & Mean & SEM \\
\hline $\mathrm{NC}$ & $14^{a}$ & 2 & $11^{\mathrm{a}}$ & 2 & $14^{\mathrm{a}}$ & 1 & $11^{\mathrm{a}}$ & 2 & $10^{\mathrm{a}}$ & 1 & $12^{\mathrm{a}}$ & 1 \\
\hline B & $25^{\mathrm{b}}$ & 4 & $31^{b}$ & 7 & $22^{\mathrm{b}}$ & 3 & $18^{\mathrm{b}, \mathrm{c}}$ & 3 & $19^{b, c}$ & 3 & $21^{b}$ & 3 \\
\hline IC & $19^{\mathrm{c}}$ & 2 & $19^{c}$ & 4 & $19^{b}$ & 3 & $17^{\mathrm{b}}$ & 2 & $17^{b}$ & 2 & $19^{b}$ & 4 \\
\hline TG & $34^{\mathrm{b}}$ & 9 & $25^{\mathrm{c}}$ & 3 & $23^{\mathrm{b}}$ & 3 & $25^{\mathrm{c}}$ & 4 & $24^{c}$ & 2 & $19^{b}$ & 3 \\
\hline
\end{tabular}

IFN, interferon; MIP, macrophage inflammatory protein; NC, normal control; B, basal; IC, infection control; TG, treated group.

a,b,c Mean values with unlike letters were significantly different $(P \leq 0.05)$

* Total cells counted at every ten fields at $1000 \times$ of magnification.

†Cytokine- and receptor-expressing cells were counted by indirect immunofluorescence in tissue sections from small intestine at $30 \mathrm{~d}$ of yacon root flour administration for NC and B groups, and for $30 \mathrm{~d}$ of administration after $7 \mathrm{dPC}$, for IC and TG. 
yacon root flour administration after $7 \mathrm{dPC}$, the histological alteration observed in the villi of the SI was similar to the IC group.

Cytokine production, like IL-10, TNF- $\alpha$, IL-12, IL- 4 and IL-6, is required to start the dialogue and maintain the activation of the different immune cells associated with the gut in physiological conditions or in the presence of a pathogen. In particular, IL-6 is involved in the differentiation of B cells to IgA plasma cells. To produce the secretory component of the S-IgA, epithelial cells need IFN- $\gamma$-mediated activation. This cytokine is mainly released by T helper type lymphocyte 1 cells ${ }^{(40)}$. For $15 \mathrm{~d}$, this cytokine was slightly stimulated by yacon after challenge (Table 3). This fact shows that yacon root flour is more effective for B-cell activation than for T cells.

The expression of TLR 4 and CD206 cell receptors and the chemokine MIP $1 \alpha+$ cells was increased in yacon groups (Table 3). The increase in the expression of these receptors would also be responsible for protection against Salmonella by yacon administration, as these receptors increase the mechanism of macrophage activity that contributes to reinforce the intestinal barrier. The increase in the expression of these receptors in the immune cells associated with the gut is important to favour the mechanism of the innate immune response, where the phagocytic activity of macrophages would be mediated through the CD206 receptor. The TLR4 receptor is an excellent signal to produce cytokines. The present results of the prebiotic effect of yacon root flour against ST differ much from other prebiotics, such as inulin ${ }^{(26,27)}$, in the protection against enteric infection. We only observed great changes in the activation of macrophages and $\mathrm{B}$ cells and not in T-cell population associated with the lamina propria of the SI.

We demonstrated that yacon root flour as a dietary supplement could be useful in preventing ST infection. The protective effect would be mediated mainly by the total S-IgA increase. Its effect is time dependent. The administration for 15 and $30 \mathrm{~d}$ was effective; longer periods of administration ( $45 \mathrm{~d}$ ) were unable to produce S-IgA or activate the innate immune cells to reinforce the epithelial barrier.

\section{Conclusion}

Yacon administration at 15 and $30 \mathrm{~d}$ was effective in the protection against ST, with $30 \mathrm{~d}$ being more effective than $15 \mathrm{~d}$. This effect would be mediated by:

(1) Increase in the total S-IgA concentration.

(2) Increase in the expression of the receptors CD206 and TLR4.

(3) Slight increase in the number of IFN- $\gamma+$ cells after challenge at $30 \mathrm{~d}$ of yacon root administration. This cytokine induces a $\mathrm{T}$ helper 1 balance that is required in ST protection

These parameters reinforce the intestinal epithelial barrier. The beneficial effect of the yacon root flour consumption found in a mouse model represents the scientific basis for the potential use of yacon root flour to prevent ST infection in human subjects.

\section{Acknowledgements}

All the authors declare that they have no competing interests in the present work. E. V., O. M. and M. E. B. B. carried out the microbiological work. E. V. performed the immunological determinations. G. P. and M. E. B. B. conceived the study. E. V. and N. C. carried out the statistics. E. V. and N. C. prepared the figures and designed the experiments. A. G. provided yacon root flour. E. V. and G. P. wrote the draft of the manuscript and supported the discussion of the results. All authors read and approved the final version of the manuscript. The present work was financially supported by PICTO 04/503, Agencia Nacional de Promoción Científica y Tecnológica (ANPyCTFONCYT) and CIUNT 26/D442 (Consejo de Investigaciones de la UNT), Argentina

\section{References}

1. Burkitt DP \& Trowell HC (1975) Refined Carbohydrate and Disease. New York, NY: Academic Press.

2. Gibson GR \& Roberfroid MB (1995) Dietary modulation of the human colonic microbiota: introducing the concept of prebiotics. J Nutr 125, 1401-1412.

3. Macfarlane SMGT \& Cummings JH (2006) Review article: prebiotics in the gastrointestinal tract. Aliment Pharmacol Ther 24, 701-714.

4. Kelly G (2009) Inulin-type prebiotics: a review (part 2). Altern Med Rev 14, 36-55.

5. Kleessen B, Hartmann L \& Blaut M (2001) Oligofructose and long-chain inulin: influence on the gut microbial ecology of rats associated with a human faecal flora. Br J Nutr 86, 291-300.

6. Voragen AGJ (1998) Technological aspects of functional food-related carbohydrates. Trends Food Sci Technol 9, 328-335.

7. Denipote FG, Trindade EB \& Burini RC (2010) Probiotics and prebiotics in primary care for colon cancer. Arq Gastroenterol 47, 93-98.

8. Scholz-Ahrens KE, Ade P, Marten B, et al. (2007) Prebiotics, probiotics, and synbiotics affect mineral absorption, bone mineral content, and bone structure. J Nutr 137, 838S-846S.

9. Boyle FG, Wrenn JM, Marsh BB, et al. (2008) Safety evaluation of oligofructose: 13 week rat study and in vitro mutagenicity. Food Chem Toxicol 46, 3132-3139.

10. Williams CM (1999) Effects of inulin on lipid parameters in humans. J Nutr 129, 1471S-1473S.

11. Lomax AR \& Calder PC (2009) Prebiotics, immune function, infection and inflammation: a review of the evidence. $\mathrm{BrJ}$ Nutr 101, 633-658.

12. Van Loo J, Cummings J, Delzenne N, et al. (1999) Functional food properties of non-digestible oligosaccharides: a consensus report from the ENDO project (DGXII AIRII-CT941095). Br J Nutr 81, 121-132.

13. Macfarlane GT \& Cummings JH (1999) Probiotics and prebiotics: can regulating the activities of intestinal bacteria benefit health? BMJ 318, 999-1003.

14. Kaur N \& Gupta AK (2002) Applications of inulin and oligofructose in health and nutrition. $J$ Biosci 27, 703-714.

15. Roberfroid MB (2000) Prebiotics and probiotics: are they functional foods? Am J Clin Nutr 71, 1682S-1687S (discussion 1688S-1690S).

16. Grau A \& Rea J (1997) Yacon. Smallanthus sonchifolius (Poepp. \& Endl.) H. Robinson. In Andean Roots and Tubers: Abipa, Arracacha, Maca and Yacon, chapter 5, pp. 199-242 
[M Hermann and J Heller, editors]. Rome: International Plant Genetic Resources Institute.

17. Valentova K, Lebeda A, Dolezalova I, et al. (2006) The biological and chemical variability of yacon. J Agric Food Chem 54, 1347-1352.

18. Graefe S, Hermann M, Manrique I, et al. (2004) Effects of post-harvest treatments on the carbohydrate composition of yacon roots in the Peruvian Andes. Field Crops Res 86, $157-165$.

19. Valentova K \& Ulrichova J (2003) Smallanthus sonchifolius and Lepidium meyenii - prospective Andean crops for the prevention of chronic diseases. Biomed Pap Med Fac Univ Palacky Olomouc Czech Repub 147, 119-130.

20. Aybar MJ, Sanchez Riera AN, Grau A, et al. (2001) Hypoglycemic effect of the water extract of Smallantus sonchifolius (yacon) leaves in normal and diabetic rats. J Ethnopharmacol 74, 125-132.

21. Valentova K, Cvak L, Muck A, et al. (2003) Antioxidant activity of extracts from the leaves of Smallanthus sonchifolius. EurJ Nutr 42, 61-66.

22. Inoue A, Tamogami S, Kato $\mathrm{H}$, et al. (1995) Antifungal melampolides from leaf extracts of Smallanthus sonchifolius. Phytochemistry 39, 845-848.

23. Valentova K, Stejskal D, Bartek J, et al. (2008) Maca (Lepidium meyenii) and yacon (Smallanthus sonchifolius) in combination with silymarin as food supplements: in vivo safety assessment. Food Chem Toxicol 46, 1006-1013.

24. Geyer M, Manrique I, Degen L, et al. (2008) Effect of yacon (Smallanthus sonchifolius) on colonic transit time in healthy volunteers. Digestion 78, 30-33.

25. Genta SB, Cabrera WM, Grau A, et al. (2005) Subchronic 4-month oral toxicity study of dried Smallanthus sonchifolius (yacon) roots as a diet supplement in rats. Food Chem Toxicol 43, 1657-1665.

26. Nakamura Y, Nosaka S, Suzuki M, et al. (2004) Dietary fructooligosaccharides up-regulate immunoglobulin A response and polymeric immunoglobulin receptor expression in intestines of infant mice. Clin Exp Immunol 137, 52-58.

27. Letellier A, Messier S, Lessard L, et al. (2000) Assessment of various treatments to reduce carriage of Salmonella in swine. Can J Vet Res 64, 27-31.

28. Benyacoub J, Rochat F, Saudan KY, et al. (2008) Feeding a diet containing a fructooligosaccharide mix can enhance Salmonella vaccine efficacy in mice. J Nutr 138, 123-129.

29. Rishi P, Mavi SK, Bharrhan S, et al. (2009) Protective efficacy of probiotic alone or in conjunction with a prebiotic in
Salmonella-induced liver damage. FEMS Microbiol Ecol 69 222-230.

30. Bibas Bonet ME, de Moreno de LeBlanc A, Dogi A, et al. (2010) Prebiotic effect of yacon (Smallanthus sonchifolius) on intestinal mucosa using a mouse model. Food Agric Immunol 21, 175-189.

31. Mastroeni P \& Sheppard M (2004) Salmonella infections in the mouse model: host resistance factors and in vivo dynamics of bacterial spread and distribution in the tissues. Microbes Infect 6, 398-405.

32. Tsolis RM, Kingsley RA, Townsend SM, et al. (1999) Of mice, calves, and men. Comparison of the mouse typhoid model with other Salmonella infections. Adv Exp Med Biol 473, 261-274

33. Kaufmann SH, Raupach B \& Finlay BB (2001) Introduction: microbiology and immunology: lessons learned from Salmonella. Microbes Infect 3, 1177-1181.

34. Santander J \& Curtiss R 3rd (2010) Salmonella enterica Serovars Typhi and Paratyphi A are avirulent in newborn and infant mice even when expressing virulence plasmid genes of Salmonella Typhimurium. I Infect Dev Ctries 4, $723-731$.

35. de Moreno de LeBlanc A, Castillo NA \& Perdigon G (2010) Antiinfective mechanisms induced by a probiotic Lactobacillus strain against Salmonella enterica serovar Typhimurium infection. Int J Food Microbiol 138, 223-231.

36. de Moreno de LeBlanc A, Dogi CA, Galdeano CM, et al. (2008) Effect of the administration of a fermented milk containing Lactobacillus casei DN-114001 on intestinal microbiota and gut associated immune cells of nursing mice and after weaning until immune maturity. BMC Immunol 9, 27.

37. Sainte-Marie G (1961) A paraffin embedding technique for studies employing immunofluorescence. J Histochem Cytochem 250-256.

38. Galdeano CM \& Perdigon G (2006) The probiotic bacterium Lactobacillus casei induces activation of the gut mucosal immune system through innate immunity. Clin Vaccine Immunol 13, 219-226.

39. Lamm ME, Nedrug JG, Kaetzel CS, et al. (1996) New insight into epithelial cell function in mucosal immunity: neutralization of intracellular pathogens and excretion of antigens by IgA. In Essentials of Mucosal Immunology, chapter 12, pp. 141-150 [M Kagnoff and H Kiyono, editors]. San Diego: Academic Press.

40. Stober D, Schirmbeck R \& Reimann J (2001) IL-12/IL-18dependent IFN-gamma release by murine dendritic cells. J Immunol 167, 957-965. 